\title{
Dynamics of Russian television news broadcasting in the context of the reflection of the COVID-19 pandemic
}

\section{Dinámica de la transmisión de noticias de la televisión rusa en el contexto del reflejo de la pandemia COVID-19}

\section{Ramis Rassyhovich Gazizov (iD}

Institute of Social and Philosophical Sciences and Mass Communications, Kazan Federal University, Russia

ORCID: https://orcid.org/0000-0002-1153-6623

Received 06-14-20 Revised 08-10-20 Accepted 09-01-20 On line 09-30-20

*Correspondence

Email: gazizov-da@yandex.ru
Cite as:

Gazizov, R.R. (2020). Dynamics of Russian television news broadcasting in the context of the reflection of the COVID-19 pandemic. Propósitos y Representaciones, 8 (SPE3), e758. Doi: http://dx.doi.org/10.20511/pyr2020.v8nSPE3.758 


\section{Summary}

This article presents an analysis of the functioning of the leading Russian television channels in March - May 2020, during the coverage of the problem of coronavirus infection. The informational priorities of channels and the linguistic aspects of presentations are investigated. The stages of coverage of the problem are determined, as well as the actors that dominate the information space. Attention is drawn to the application of event interpretation techniques, the implementation of new forms of television broadcasting in Russia under the influence of a new virus pandemic. Analyzed the information issues that appeared on television channels: "First", "Russia 1", "Russia 24", "NTV". The reports of Murat Zaripov on Rossiya 1 channel, Mikhail Chernov on NTV channel, which touched upon current issues of the pandemic in Russia and the central problem are rather clearly presented: the restrictions of the authorities introduced to save the lives of citizens and people's unwillingness to comply with the restrictions are analyzed. A personality protest aimed at realizing one's own desires and ignoring social norms has become one of the most characteristic phenomena during the coverage of the topic of coronavirus infection. The most frequent images are distinguished: "doctors - rescuers", violators, volunteers. New terms are formulated and updated: medical authorities, plateau, self-isolation index, selfisolation, self-preservation. The determination of these and other data allows us to better understand the specifics of coverage of the topic of a new coronavirus infection by leading Russian television companies.

Keywords: television, Russian television, covid-19

\section{Resumen}

Este artículo presenta un análisis del funcionamiento de los principales canales de televisión rusos en marzo-mayo de 2020, durante la cobertura del problema de la infección por coronavirus. Se investigan las prioridades informativas de los canales y los aspectos lingüísticos de las presentaciones. Se determinan las etapas de cobertura del problema, así como los actores que dominan el espacio de información. Se llama la atención sobre la aplicación de técnicas de interpretación de eventos, la implementación de nuevas formas de transmisión de televisión en Rusia bajo la influencia de una nueva pandemia de virus. Se analizaron los temas de información que aparecían en los canales de televisión: "Primero", "Rusia 1", "Rusia 24", "NTV". Los informes de Murat Zaripov en el canal Rossiya 1, Mikhail Chernov en el canal NTV, que abordaron los problemas actuales de la pandemia en Rusia y el problema central se presentan con bastante claridad: las restricciones de las autoridades introducidas para salvar las vidas de los ciudadanos y la falta de voluntad de las personas. para cumplir con las restricciones se analizan. Una protesta de la personalidad destinada a realizar los propios deseos e ignorar las normas sociales se ha convertido en uno de los fenómenos más característicos durante la cobertura del tema de la infección por coronavirus. Se distinguen las imágenes más frecuentes: "médicos rescatistas", infractores, voluntarios. Se formulan y actualizan nuevos términos: autoridades médicas, meseta, índice de autoaislamiento, autoaislamiento, autoconservación. La determinación de estos y otros datos nos permite comprender mejor los detalles de la cobertura del tema de una nueva infección por coronavirus por parte de las principales compañías de televisión rusas.

Palabras clave: televisión, televisión rusa, covid-19

\section{Introduction}

The problems associated with the reflection in the media of information about a new coronavirus infection have acquired particular relevance and a special scale. She defined the "agenda", redistributing other relevant topics and processes in it, and came to the fore in Russian media. 
This was actively observed throughout March, April and, to a lesser extent, May 2020. Russian television has been actively involved in the processes of informing Russians, providing operational information and a wide panorama of events.

The author identifies the following stages of reflection of the topic. Taking into account the global specifics: Stage 1 (February - March 2020) - foreign events: covers the period of incidence mainly in China and some other neighboring countries (Japan, South Korea, etc.); Stage 2 (March - April 2020) - the spread of a new virus in the United States of America, in Europe. In Russia, this stage is characterized by an increase in the number of diseases of coronavirus infection, the introduction of restrictive measures: self-isolation, the active introduction of forms of distance work and study.

Given the Russian specifics: Stage 1 (February - March 2020), which is characterized by the following events. March 25 - the first appeal of the President of Russia to citizens, a week off is announced with the preservation of wages. This is a transition to self-isolation mode, the time of remote work and study. People from cities rush to villages. It becomes known about the diseases of famous pop singers: L. Leshchenko, N. Babkina. The chief doctor of the hospital in Kommunarka, D. Protsenko, is one of the first to show the vulnerability of doctors to the new virus. Anti-heroes appear in the media - doctors: the chief infectious disease specialist of the Stavropol Territory I. Sannikov, the chief physician of the oncological clinic in the Perm Territory M. Mezentsev, who returned from foreign countries, became ill with coronavirus, ignored the regime of self-isolation and infected other people. Scammers offering amulets, miracle cats and enchanted banks with tomatoes are activated.

TV channel "Russia - 24" launches a large-scale action "We sit at home." Broadcasting is conducted by the presenters from their homes, thereby urging the Russians to follow suit. Stage 1 March 16 - March 22, 2020 - the first restrictive measures in educational institutions. The first cases appear. Stage 2 March 23 - March 29 - the first general self-isolation

V. Putin visits a hospital in Kommunarka - the first hospital for patients with coronavirus. Despite the onset of the pandemic, the heads of regions are resigning. Stage 3 March 30 April 30 increased self-isolation, measures are tightened.

The Russia-24 TV channel broadcasts documentaries on infectious diseases: Smallpox, Invisible Microbial Power, whose task is to show the danger of viruses.

\section{Methods}

In the course of the study, the author used methods of meaningful and structural analysis, which made it possible to identify the specifics of the information presented on Russian television. Comparative analysis allowed us to identify the distinctive features of the information presented to the mass audience.

Television communications have been and remain an object of close attention of a wide range of Russian and foreign scientists.

The study of issues covered in the media is divided into the study of the functioning of television communications (Zwick, 2004; Nauka, 2005; Hargrave \& Shaw, 2009; Ilchenko, 2009; Smith \& Higgins, 2013); determination of the specifics of the broadcast model (Stephens, 2005; Graham, 2004). Scientists also focus on the issues of determining linguistic, genre and other structural and substantive aspects (Lukov, 2006; Chobanyan, 2018; Montgomery, 2007).

\section{Results and Discussion}


The structure of news releases during the pandemic:

1) The situation with coronavirus in the country;

2) Block of domestic political information (economics, construction)

3) Coronavirus in the world

4) Other news

Analysis of one of the issues of the TV channel "Russia 1". The issue opened with information about the incidence in the country, then - it was about the development of the medical industry, after which news from the regions was presented. Channel 1 initially provided information on the incidence rate, then came news from the regions; reports from hospitals: Moscow City Research Institute of Emergency Medicine named after N.V. Sklifosovsky, City Clinical Hospital named after S.P. Botkin. NTV also informed viewers about the situation with COVID19 in the world, social problems, and the functioning of various branches of Russian industry.

A distinctive feature of the "agenda" of Russian channels during March - April 2020 is the priority of messages on the topic of coronavirus in news releases. However, starting in the second half of April, other events gradually come to the fore: for example, the celebration of Easter, as well as a gas explosion in the city of Orekhovo-Zuevo. These features are explained by the scale and significance of these events, their resonance, and the presence of victims.

Journalists from Russian federal channels are beginning to actively apply new forms of news reporting: NTV channel correspondents get from home to work, describing the process. The objectives of the plot authors: 1) to prepare materials using available resources under quarantine restrictions; 2) show the difficulties of the first morning after the introduction of passes, having felt all the features of the trip of ordinary citizens in public transport.

TV channel "Russia - 24" goes to the remote mode. The presenters go on air from home, setting an example to other Russians in terms of distance work and contributing to the formation of a sustainable transition to new forms of work in the country. The television channel NTV is changing the studio, emphasizing that this is done in order to minimize contacts between employees and prevent disease.

Among the most frequently mentioned media personalities are: V. Putin, M. Mishustin, S. Sobyanin, T. Golikova, A. Popov, V. Skvortsov. Each of them is a leader responsible for implementing measures to counteract a new infection and protect citizens.

The hierarchy of actors. Representatives of the government - the president, prime minister, ministers, incl. Head of Ministry of Health, Head of Rospotrebnadzor. Experts are heads and representatives of Russian research institutes, the head and representatives of the Federal Medical and Biological Agency, chief doctors of hospitals, and individuals in the healthcare sector. Citizens are Russian participants: eyewitnesses, the sick, their relatives. Foreign participants: sick, their relatives.

\begin{tabular}{|c|c|c|}
\hline № & Characters & Broadcast Forms \\
\hline 1 & Representatives of the authorities & Informing and commenting \\
\hline 2 & The experts & Assessment and Forecasting \\
\hline 3 & Citizens & Opinion, Attitude \\
\hline 4 & Foreign participants & Opinion, appeal \\
\hline
\end{tabular}


Recommendations of doctors, consisting in the need to strengthen sanitary and hygienic measures, limit contacts. The famous speaker and TV presenter, chief doctor of the Moscow city hospital Alexander Myasnikov becomes the official speaker. The particular presence in the television information space of the leaders and chief doctors of Moscow hospitals is explained by the fact that it was there that the greatest number of cases was noted, and an impressive bed fund was deployed. The reports from the "red zone" were a continuation of the information work aimed, on the one hand, to inform viewers; on the other, they were proactive in nature, designed to reduce the activity of citizens during a pandemic.

Television appeals from the authorities were designed to convince citizens to comply with self-isolation measures, quarantine measures. Among the measures taken: police raids, stricter liability and increased fines. Active explanatory work was carried out: it must be said that at the beginning neither the media, nor citizens could clearly separate the essence of these concepts, as a result of which collisions arose. Self-isolation - restrictive preventive measures introduced by the government during the period of struggle with a new virus. Quarantine - refers to persons who have become infected with the virus and who have contacted them.

"Sick" on the air - to show the danger of the disease, its complex course. Among them, at first there were patients from foreign clinics, then Russian citizens.

Active participants in the television space during this period were representatives of the medical community. Consider the images of doctors on television. One of the first doctors shown in the context of the fight against coronavirus infection was D. Protsenko, the head doctor of the Moscow City Clinical Hospital No. 40. For example, in the publications of the Russian newspaper Kommersant, he was a symbol of the fight against coronavirus in Russia. The hospital, which he heads, was the first clinic converted to receive patients with a new coronavirus infection. On March 24, 2020, the institution was visited by Russian President Vladimir Putin, who praised the work of the clinic and the head doctor. On March 31, 2020, D. Protsenko was diagnosed with coronavirus. The doctor often appeared on television, commenting on the situation, and actively shared information on his pages in social media. Thus, D. Protsenko frequent references on the air, shared the latest and exclusive information, which allows us to talk about a bright positive image.

Along with doctors who had a positive image, there were also those who had negative characteristics. A number of representatives of the medical industry in Russia, mainly those who returned from abroad, were carriers of the virus. They could not stand the quarantine, but immediately set about fulfilling their duties, having begun active work. They were diagnosed with coronavirus later, when they already managed to create infection risks for other people. Among them is Irina Sannikova, the former chief infectious disease specialist of the Stavropol Territory, doctor of medical sciences, professor of the Stavropol State Medical University. Below, based on the data of television channels, a comparative characteristic of media images by I. Sannikova and D. Protsenko is presented.

Table 2.

Comparative analysis of media characters-antipodes

\begin{tabular}{|c|c|c|c|}
\hline \multirow{2}{*}{ № } & \multirow{2}{*}{ Criteria } & Irina Sannikova & Denis Protsenko \\
\cline { 3 - 4 } & Official status & $\begin{array}{c}\text { Chief Freelance Infectious Disease } \\
\text { Specialist of the Stavropol Territory, } \\
\text { University Professor }\end{array}$ & $\begin{array}{c}\text { Head doctor of the city clini- } \\
\text { cal hospital № 40 }\end{array}$ \\
\hline 22 & Mediastatus & «Intruder», «Doctor Evil», «Sorrow & «Savior», «symbol of the \\
\hline
\end{tabular}




\begin{tabular}{|c|c|c|c|}
\hline & & is a Doctor» & $\begin{array}{c}\text { fight against coronavirus», } \\
\text { «victim» }\end{array}$ \\
\hline 33 & $\begin{array}{c}\text { The influence of } \\
\text { the media status } \\
\text { on official status }\end{array}$ & $\begin{array}{c}\text { «Former chief freelance infectious } \\
\text { disease specialist of the Stavropol } \\
\text { Territory» }\end{array}$ & The current head of the clinic \\
\hline 44 & $\begin{array}{c}\text { The nature of the } \\
\text { media image }\end{array}$ & Negative: criticism & Positive: support \\
\hline
\end{tabular}

Images of violators are actively represented - those who, for various reasons, violated the quarantine and self-isolation regimes. Most often these were private individuals: "lovers of barbecue in nature", "athletes", "participants in illegal night races in Kommunarka." However, there were also shadow business lines: for example, "illegal mini-hotels of Crimea", "illegal services", and so on. Objectives: to show the dangers of such risk-taking behavior; emphasize that the law is being violated and responsibility will follow. In the process of creating images, journalists focused on such features as indifference and selfishness.

Table 3.

News feed structure: "agenda" of April 9, 2020 (10.00 - 11.00)

\begin{tabular}{|l|c|c|}
\hline \multirow{2}{*}{ Criteria } & «HTB» & \\
\cline { 2 - 3 } & Incidents & Medical information \\
\hline \multirow{3}{*}{} & Medical information & Incidents \\
\cline { 2 - 3 } & Economy & Economy \\
\cline { 2 - 3 } & &
\end{tabular}

The images of volunteers are young people seeking to help older people and everyone who needs help during a pandemic. Students, representatives of small and medium-sized businesses, caring Russians, foreign citizens - this is the range of roles of participants in the volunteer movement in television discourse.

Fatigue of people. An example of this is the report by Mikhail Chernov on NTV channel, dedicated to the situation in the hostel of Yekaterinburg on Tupu lane. The foci of coronavirus infection found there made the inhabitants of this hostel "hostages" of the quarantine regime, and after a 2-week stage, another followed, as new cases were identified. The main characters are people, authorities. social problem, the essence of which is contained in the phrase: "Sit all summer if you do not want to follow the rules." Here we see a clash of individual freedom and restrictions of power and society, unwillingness to comply with the requirements of the authorities, the priority of personal interests over social ones.

Let's consider new terms. Let us compare new terms and well-known terms: their usual meaning and the new, media, already - television meaning.

Self-isolation index - an indicator developed by Yandex specialists and based on data on the use of various system services. In television practice, the term allowed us to identify regions with a high index as positive examples that should be looked at; and regions with a low index as negative examples, and this information transmitted on television is designed to mobilize their residents to comply with anti-epidemic measures. 
Evidence-based medicine - in the practice of TV, it is connected with issues of organizing healthcare, technologies that have been tested experimentally and have proven effective in treating a new coronavirus infection. Television is becoming the main translator of the innovations of the pharmaceutical market. Journalists emphasize the responsiveness and flexibility of medical structures in determining the optimal treatment methods, taking into account the latest data and both international and Russian experience.

"Medical authorities" - the leading role of healthcare structures is emphasized, their influence on decision-making in all areas and determining the prospects for the development of Russian society. Characteristic features: active presence in the public space and the primary attention of the media to these topics. Leading organizations: Ministry of Health, Federal Service for Supervision of Consumer Rights Protection and Human Well-being, Federal Medical and Biological Agency. These structures are an integral part of the federal executive branch, which are under the jurisdiction of the Government of Russia, and are endowed with control and oversight functions in the field of medicine. Key newsmakers: Minister of Health M. Murashko, head of the Federal Service for Supervision of Consumer Rights Protection and Human Wellbeing A. Popova, head of the Federal Medical and Biological Agency V. Skortsova.

Self-isolation is a term that gained relevance at the end of March and involves the restriction of contacts, exits from the house, the predominant transition to remote work and distance learning. The voluntary nature of this term is subsequently replaced by a new meaning, the mandatory implementation and liability for violation are emphasized.

Self-preservation is a concept that has become relevant at the first stage of quitting quarantine measures; involves a strict adherence to preventive measures, the use of protective equipment elements.

Plateau - attention to the term intensifies in late April - early May 2020, and is associated with the expectation of a peak in the pandemic and its subsequent stabilization. One of the first in public space about the speediest way out on the plateau is expressed by the head of the Federal Medical and Biological Agency V. Skortsova.

The Crown Crisis is the global nature of the pandemic, its impact on all spheres of society. This mainly means a fall in the economy, a reorientation of industry to the fight against coronavirus infection. In a narrower sense in the practice of TV: stopping a business, bankruptcy, people losing their jobs. Special attention is paid to the Russian television broadcasting issues of bank lending.

Covid hospital - medical facilities that have been converted or built to receive patients with a new coronavirus infection. Existing and new institutions.

Covid statistics - the number of patients who recovered and died from a new infection.

The television information system for coronavirus infection was represented by the following elements:

1. News releases.

2. Analytical programs.

3. Talk shows.

4. Social advertising.

5. Documentary film.

\section{Summary}

TV channel "Russia" goes live - from home. Journalists get home from work, showing it on the air and shooting on mobile devices. 
Active dissemination of reports from the "red zone", which were a continuation of the information work aimed, on the one hand, to inform viewers; on the other, they were proactive in nature, designed to reduce the activity of citizens during a pandemic.

\section{Conclusions}

The topic of coverage of coronavirus infection has gained particular importance in modern media. We analyzed the first stage - the stage of the appearance of the virus and the reaction to it from the authorities and society. Further research will have prospects, provided the disease is relevant.

\section{Acknowledgements}

The work is performed according to the Russian Government Program of Competitive Growth of Kazan Federal University.

\section{References}

Chobanyan, K. (2018). Modern Information Channel: Genre Priorities and language model: monograph-M .: Fak. Journal Moscow State University,. $202 \mathrm{~s}$

Graham, D. (2004). Public service broadcasting without BBC? Institute of Economic Affairs (Great Britain).

Hargrave, A.M., \& Shaw, C. (2009). Accountability and the public interest in broadcasting. Houndmills: Palgrave-Macmillan.

Ilchenko, S.N. (2009). Domestic television at the turn of the century. St. Petersburg: Publishing House St. Petersburg State University, - 468 p.

Lukov, M.V. (2006). Television: constructing a culture of everyday life. Abstract for the degree of candidate of philosophical sciences. -M .: Moscow State University,-22 p.

Montgomery, M. (2007). The Discourse of the Broadcast News: A Linguistic Approach. - London: Routledge.

Nauka, (2005). Television journalism. - M.: Publishing house Mosk. University. - 366, [1] p.

Smith, A., \& Higgins, M. (2013). The Language of Journalism: A Multi-Genre Perspective. London.

Stephens, M. (2005). Broadcast News. - Belmont.

Zwick, V.L. (2004). Television Journalism: History, Theory, Practice: Textbook. - M .: Aspect Press, $382 \mathrm{p}$. 